\title{
Regional representativeness assessment and improvement of eddy flux observations in China
}

\author{
Honglin He ${ }^{\mathrm{a}, *}$, Liyun Zhang ${ }^{\mathrm{a}, \mathrm{b}}$, Yangzi Gao ${ }^{\mathrm{a}}$, Xiaoli Ren ${ }^{\mathrm{a}, \mathrm{b}}$, Li Zhang ${ }^{\mathrm{a}}$, Guirui Yu ${ }^{\mathrm{a}}$, Shaoqiang Wang ${ }^{\mathrm{a}}$ \\ ${ }^{a}$ Key Laboratory of Ecosystem Network Observation and Modeling, Institute of Geographic Sciences and Natural Resources Research, Chinese Academy of Sciences, Beijing 100101, China \\ ${ }^{\mathrm{b}}$ University of Chinese Academy of Sciences, Beijing 100049, China
}

\section{H I G H L I G H T S}

- The network of flux towers performed well in representing the environment of more than half of China.

- The towers in wetlands and barelands were poorly represented.

- Representativeness increased with towers added in forests, grasslands, wetlands and barelands.

- Substantial gains in representation were achieved by adding new towers on the Tibet Plateau.

\section{A R T I C L E I N F O}

\section{Article history:}

Received 17 December 2013

Received in revised form 20 July 2014

Accepted 22 September 2014

Available online 10 October 2014

Editor: Xuexi Tie

\section{Keywords:}

Representativeness

Flux tower

Euclidean distance

Environmental variable

Additional tower

\begin{abstract}
A B S T R A C T
Both the amounts of data describing the site-scale carbon flux at a high temporal and spatial resolution collected in China and the number of eddy covariance flux towers have been increasing during the last decade. To correctly upscale these fluxes to the regional and global level, the representativeness of the current network of flux towers must be known. The present study quantifies the representativeness of the flux network for the regional carbon exchange. This analysis combined the total solar radiation, air temperature, vapor pressure and the enhanced vegetation index to indicate the environmental characteristics of each $1-\mathrm{km}$ pixel cell and flux tower. Next, the Euclidean distance from each pixel to the tower was calculated to determine the representativeness of the existing flux towers. To improve the regional representativeness, additional tower locations were pinpointed by identifying and clustering the underrepresented areas. The existing network of flux towers performed well in representing the environmental conditions of the middle and the northeastern portions of China. The wellrepresented areas covered $60.9 \%$ of the total areas. The towers in croplands and grasslands represented the vegetation types well, but the wetlands and barelands were poorly represented. The representativeness of the flux network increased with the addition of nine towers located in forests, grasslands, wetlands and barelands. The representativeness of $27.5 \%$ of the land areas improved. In addition, the well-represented areas were enlarged by $15.2 \%$. Substantial gains in representation were achieved by adding new towers on the Tibet Plateau. The representativeness of the northwest and southwest was improved less significantly, suggesting that more towers are required to capture certain ecosystem behaviors.
\end{abstract}

(c) 2014 Elsevier B.V. All rights reserved.

\section{Introduction}

Terrestrial ecosystems play an important role in the global carbon cycle, especially in the context of global change and climate policymaking (Yu et al., 2013). Terrestrial ecosystems exchange approximately $120 \mathrm{Gt}$ of carbon per year with the atmosphere through the processes of photosynthesis and respiration (Gonzalez-Meler et al., 2004; Schlesinger, 1997). A small change in terrestrial carbon exchange could have a significant impact on the $\mathrm{CO}_{2}$ increment in the atmosphere (Amthor, 1997). Previous studies have indicated that a large number

\footnotetext{
* Corresponding author. Tel.: +8610 64889599; fax: +861064889399.

E-mail address: hehl@igsnrr.ac.cn (H. He).
}

of climatic (temperature, radiation, precipitation), geochemical (nutrients, soil composition) and ecological (species, age) factors affect the terrestrial carbon cycle (Chapin et al., 2002; Chen et al., 2013; Granier et al., 2007; Thornton et al., 2002). Therefore, accurate quantification of the capability of carbon exchange in various terrestrial ecosystems is essential for understanding the global carbon cycle (Canadell et al., 2004).

By observing atmospheric turbulence, the eddy covariance technique is one of the most direct and defensible methods to estimate the exchanges of carbon dioxide, water vapor and heat between the atmosphere and the land surface. The technique is closely related to physiological and ecological processes and can reflect the seasonal and interannual variability of carbon fluxes (Baldocchi et al., 2001; Chen 
et al., 2013). Since being established in the early 1990s, eddy covariance flux towers have provided continuous measurements of the ecosystemlevel net exchange of carbon (Wofsy et al., 1993). The FLUXNET is the global network of flux towers (Baldocchi et al., 2001). There are currently approximately 541 towers registered on the FLUXNET (http://wwweosdis.ornl.gov/FLUXNET/), which are distributed in different ecosystems and climate zones all over of the globe (Baldocchi, 2008).

The Chinese Terrestrial Ecosystem Flux Observation and Research Network (ChinaFLUX), launched in 2002, fills an important regional gap in FLUXNET and increases the number of ecosystem types being monitored by long-term observations (Yu et al., 2006). Since its establishment, ChinaFLUX has developed rapidly and expanded from the initial eight sites into a national scale network, with observation sites covering most of the terrestrial ecosystem types in China (Fu et al., 2010). The network of flux towers in China provides extensive and reliable measurements of the $\mathrm{CO}_{2}, \mathrm{H}_{2} \mathrm{O}$ and energy fluxes with high temporal and spatial resolution, which enables the estimation and prediction of the respective spatiotemporal variability of the carbon and water cycles under the global climate change scenario (He et al., 2010; Fu et al., 2010; Yu et al., 2013; Wang et al., 2013). To correctly upscale these fluxes to regional and global level, the representativeness of the current network is an important aspect to consider (Sulkava et al., 2011).

The representativeness of a network refers to the ability to reproduce the main characteristics of the quantities or processes of the population under study (Sulkava et al., 2011). Several studies have attempted to quantify the representativeness of the flux network for the carbon exchange of the various ecosystems (Nappo et al., 1982; Valentini, 2003). The methods used in these research studies could be summarized into two approaches: cluster-based and pixel-based. Although both approaches eventually use the Euclidean distance in the representativeness quantification, the first approach additionally delineates ecoregions using a k-means cluster analysis. The cluster-based method has been used intensively, see, e.g., Hargrove and Hoffman (2003), Hargrove and Hoffman (2004a,b), Hoffman et al. (2008, 2013) and Sulkava et al. (2011). The second approach directly calculates the Euclidean distances between the pixels and the tower sites. Recently, this approach has been used in many previous investigations to determine the network representativeness at a range of spatial and temporal scales (Carvalhais et al., 2010; Xiao et al., 2011; Yang et al., 2008).

Despite the relatively large number of flux towers in operation across China, the representativeness of the current flux network is still insufficient. Currently, the previous studies are primarily performed at individual geographic points. The tower measurements only represent fluxes at the scale of the tower footprint (i.e., the ecosystem level) ranging from a few hundred meters to several kilometers (Gong et al., 2009; Mi et al., 2006; Shuang et al., 2009; Xiao et al., 2012). Wang et al. (2014) recently studied the spatial distribution of flux towers in relation to the newly generated flux ecoregions and compared the land areas of ecoregions with the existing geographical regionalization. China is characterized by a complex topography, heterogeneous regional climates and various types of ecosystems (Yu et al., 2006). Although individual towers provide important information about the carbon flux in the immediate area surrounding each tower, the regional representativeness of the flux networks will influence the accuracy of the gridded flux estimates derived from tower fluxes (Xiao et al., 2012). Therefore, it is necessary to determine the degree of the flux environment across China represented by the existing network of eddy flux towers.

Quantifying the representativeness of the network is important for optimal network design, thus avoiding unnecessary duplication and maximizing the coverage of the monitoring network. This study utilizes data collected from flux towers at 91 different locations to reflect the existing flux network in China. To maximally improve the representativeness capacity of the current network, new towers were also proposed. Thus, the specific objectives of this study are to (1) estimate the representativeness of the flux towers on the regional scale and (2) determine the optimal additional tower locations.

\section{Data and methods}

\subsection{Data}

\subsubsection{Tower locations}

There are 91 flux towers in mainland China that were used in this study, which cover the major ecosystem types in China (Fig. 1). These 91 towers were grouped into the following vegetation types: coniferous forests (CF, 9 towers), broadleaf forests (BF, 14 towers), mixed forests (MF, 8 towers), grasslands (GL, 19 towers), wetlands (WL, 8 towers), croplands (CL, 26 towers), and barelands (BL, 7 towers) (Table A.1). Fig. 1 shows the distribution of the collected flux towers.

\subsubsection{Selection of the environmental variables}

Both the water and $\mathrm{CO}_{2}$ flux exchanges were associated with the patterns of the meteorological variables, such as wind, temperature, precipitation and sunlight (Qin et al., 2008; Gao et al., 2013). Three meteorological variables, i.e., total solar radiation (RAD), air temperature (TEM), and vapor pressure (VAP), were chosen to represent the landatmosphere energy and water exchanges, which have a direct impact on vegetation photosynthesis and respiration (Dan et al., 2005). For example, Wang et al. (2008) found that air temperature was one of the most important factors that controlled the patterns and variations of $\mathrm{CO}_{2}$ exchange between the atmosphere and the steppe. Gao et al. (2013) also reported that the temperature increase had a greater influence than the precipitation changes on productivity in the Tibetan Plateau region. Thomas et al. (2011) found that the solar radiation had the largest influence on the daily values of the $\mathrm{CO}_{2}$ fluxes, while temperature appeared to be the driver of the ecosystem respiration variation.

The vegetation indices derived from the satellite images are very useful to model and predict the vegetation carbon exchange (Gurung et al., 2009). The enhanced vegetation index (EVI) was selected because the vegetation physiological properties have an important effect on carbon exchange (Yang et al., 2008). The EVI is less sensitive to soil and atmospheric effects than the normalized difference vegetation index (NDVI) because it incorporates the blue spectral band. The EVI is directly related to the photosynthetic production of plants and indirectly related to the green biomass (Huete et al., 2002). As a result, the EVI remains sensitive to increases in canopy density beyond the level where the NDVI becomes saturated (Huete et al., 2002). Xiao et al. (2004) also found that the EVI had a stronger linear relationship with the gross primary production than did the NDVI.

\subsubsection{Data sources}

To analyze the representativeness within and among the years of operation of the existing network, we chose a spatial resolution of $1 \mathrm{~km}$ and a temporal resolution of 1 month in the period of 2005-2010. The climate data, i.e., RAD, TEM, and VAP, of 728 weather stations (China Meteorological Data Sharing Service System, http://cdc.cma.gov.cn/home. do) were interpolated using the ANUSPLIN package (Hutchinson, 1991, $1995,1998,2002)$. The monthly meteorological data were interpolated using thin plate smoothing splines based on the topography. Data from Taiwan were not included in this study. Before the $1-\mathrm{km}$ resolution dataset was developed, a rigorous quality control process was used to ensure the accuracy of data from the weather stations. This process involves careful outlier identification and errors correction, based on the method of Feng et al. (2004). A total of $1.46 \%, 1.09 \%$ and $1.25 \%$ of the monthly values of RAD, TEM, and VAP were eliminated respectively. The remaining quality control passed meteorological data was spatially interpolated to $1-\mathrm{km}$ resolution. Lots of data cleaning and quality control were performed also when the interpolations were proceeding.

To calculate the EVI of each pixel and tower, we formed a mosaic of the MODIS tiles and resampled this mosaic with the MODIS Reprojection Tool MOD13A3 (https://lpdaac.usgs.gov/products/modis _products_table/mod13a3). The 1:1,000,000 scale vegetation map of 2005 in China (Editorial Board of Vegetation Map of China, 2007) was 


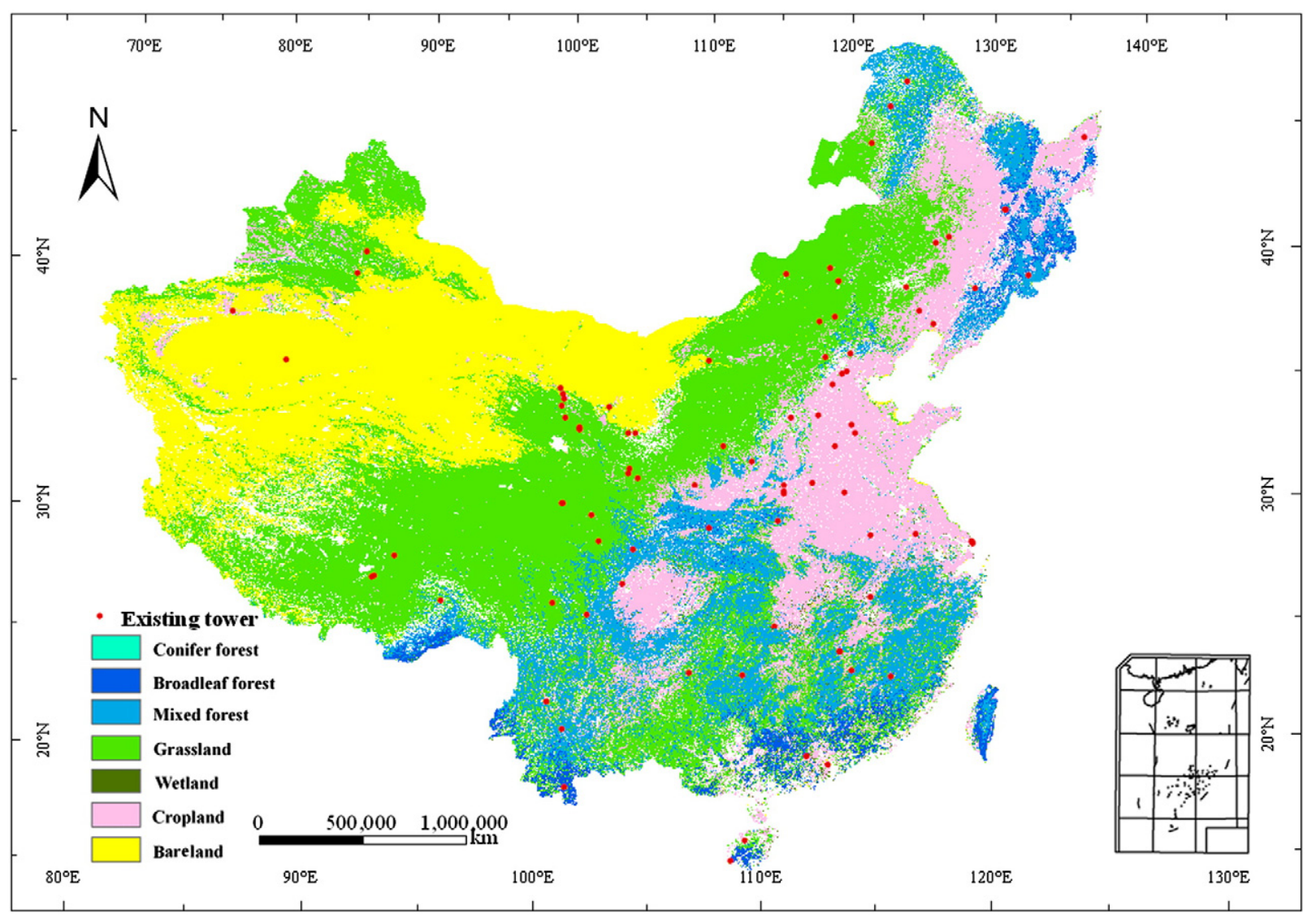

Fig. 1. The study region and the locations of the 91 flux towers and vegetation types in China.

re-classified to produce a local 1-km resolution land map using seven broader classes, i.e., $\mathrm{CF}, \mathrm{BF}, \mathrm{MF}, \mathrm{GL}, \mathrm{WL}, \mathrm{CL}$, and $\mathrm{BL}$. The vegetation type was assumed to be stable in the period of 2005-2010.

\subsection{Methods}

\subsubsection{Temporal representativeness}

The temporal representativeness of the existing flux network was assessed by comparing the monthly variations of RAD, TEM, VAP and EVI from the flux towers with those from the pixels. The means and standard deviations of the monthly environment data (RAD, TEM, VAP and EVI) for the towers and the cells were calculated by vegetation type. The analysis of variance (ANOVA) was also applied to determine whether the difference in means was significant. All the tests were performed at an $\alpha=0.05$ level of significance.

\subsubsection{Spatial representativeness}

We estimated the representativeness of the eddy covariance network using the Euclidean distance between each pixel and tower in the attribute space, following the method of Yang et al. (2008). The Euclidean distance is defined as the shortest straight line distance between two points, in this case, the distance between the studied tower and the coterminous pixel in the 4-dimensional environmental space (Yang et al., 2008). First, the monthly environment matrix over the period of 2005-2010 was standardized to zero mean and unit variance. Second, the Euclidean distances from a pixel to each tower were calculated, and the minimum distance and the corresponding tower were selected in this study. The minimum distance indicates how well the environmental condition of the flux tower represents the combination of conditions of the selected pixel. The pixels with low Euclidean distance values were environmentally similar to the nearest tower (Hoffman et al., 2008). By calculating the minimum value for every pixel, maps of the regional representativeness of flux towers were produced (Hoffman et al., 2013). Third, the importance value of each tower was calculated by counting the number of pixels on the tower that have the minimum distance to the tower (Hargrove and Hoffman, 2003). The average of the minimum distances of each tower was also calculated to find out how well the tower represents pixels on it. The tower that has a lower average of the minimum distances has a better representativeness. Finally, the average of the minimum distances of the whole region was used as the indicator of how well the environment at the pixel was represented by the existing towers. The poorly represented areas were identified as pixels that have a distance to the nearest flux tower larger than the average value.

\subsubsection{Pinpointing the additional tower locations}

After quantifying the regional representativeness of the current flux network, the next challenge is to maximize the network coverage. The optimal addition of tower locations that could best represent the environmental conditions of the poorly represented areas is desirable. The $\mathrm{k}$-means cluster analysis was applied to find the best new locations at the poorly represented areas. The clustering used the same four rescaled variables (RAD, TEM, VAP and EVI), which were defined earlier. The studied areas were parsimoniously grouped into nine distinct classes. The centroids of the nine groups were determined by the k-means algorithm (Hartigan, 1975). The centroids were then assigned to the nearest pixel using the Euclidean distance calculation, and the nine assigned pixels became the new tower locations that we recommended. Because of the high spatial and temporal resolution, our data analysis was performed in parallel using a computer cluster. 

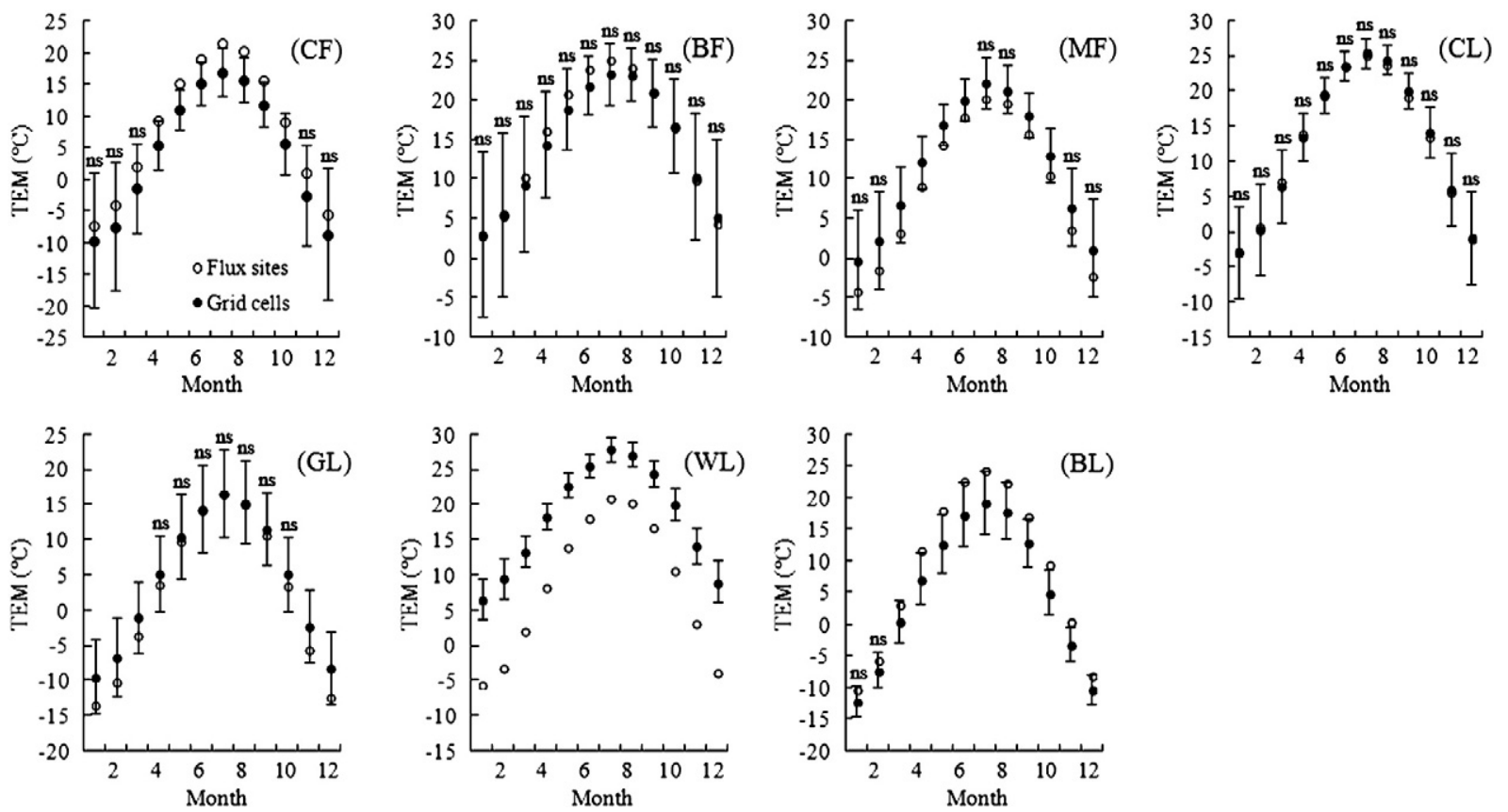

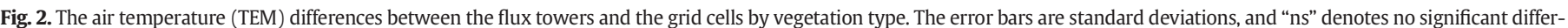

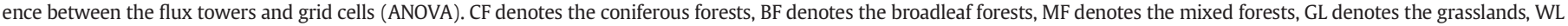
denotes the wetlands, $\mathrm{CL}$ denotes the croplands and BL denotes the barelands (the same abbreviations are used below).

\section{Results}

\subsection{Temporal representativeness}

The environmental differences (i.e., TEM, RAD, VAP and EVI) between the towers and the pixels were examined for each vegetation type and environmental variable, respectively. The comparisons indicated that the distribution of the flux network of the mean TEM generally followed the pattern of the grid cells of the same vegetation type, except for $\mathrm{WL}$, where the data from the towers were approximately
$7-12{ }^{\circ} \mathrm{C}$ lower than the data from the pixel areas (Fig. 2). The standard deviations were generally wider during spring and winter than during summer and fall for forests (CF, BF and MF), CL and WL. An analysis of the monthly variations in RAD indicated that the network and grids had similar distributions of the mean RAD. The RAD of the WL towers was in the range of $0.8-5.2 \mathrm{MJ} \mathrm{m}^{-2}$ day $^{-1}$ higher than that of the grid cells and was at its maximum in May, which was two months ahead of the peak of the grid cells (Fig. 3). The monthly variations in VAP indicated that the standard deviations were wider during the growing season than during the non-growing season (Fig. 4). The mean VAP of the
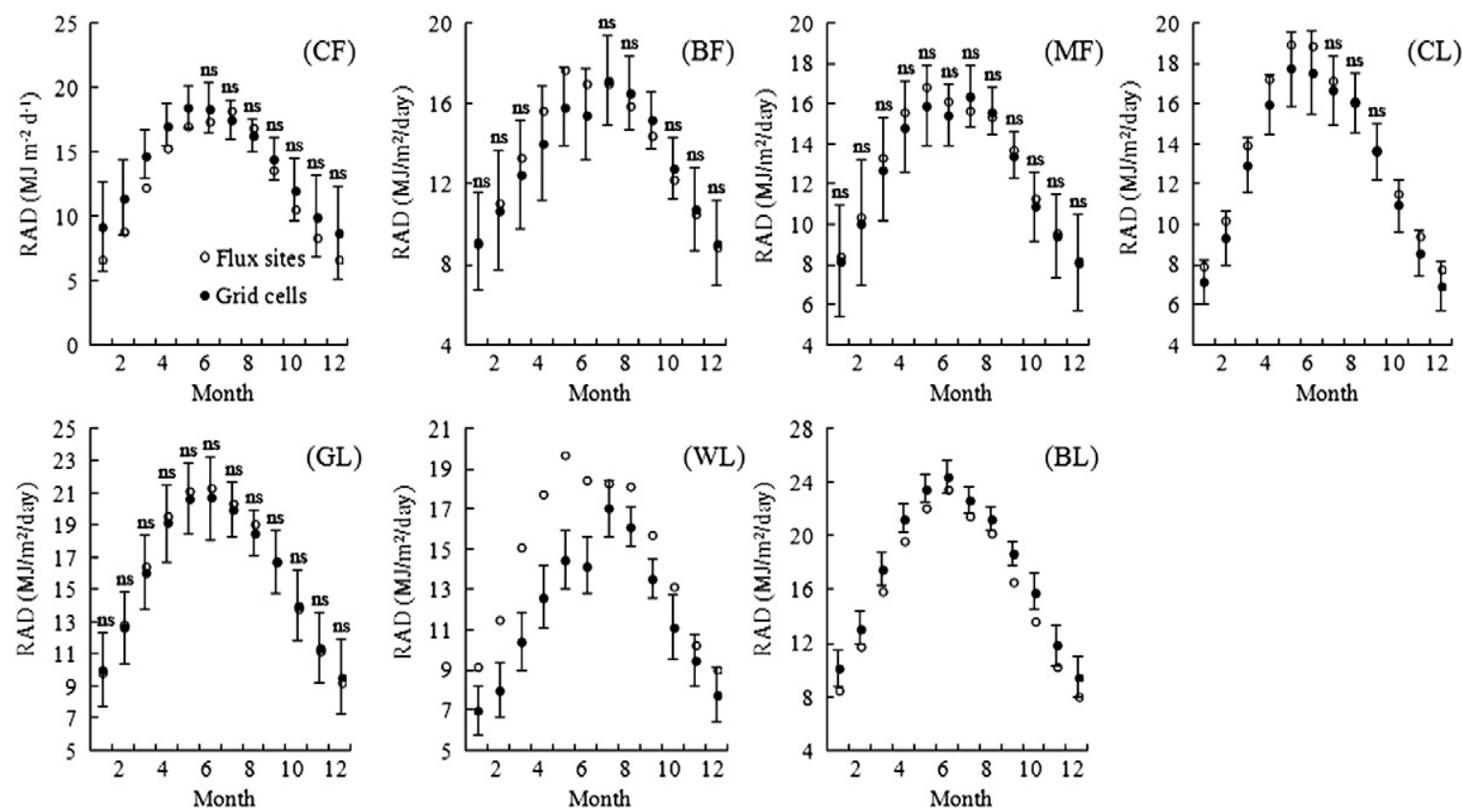

Fig. 3. The total radiation (RAD) differences between the flux towers and the grid cells by vegetation type. 

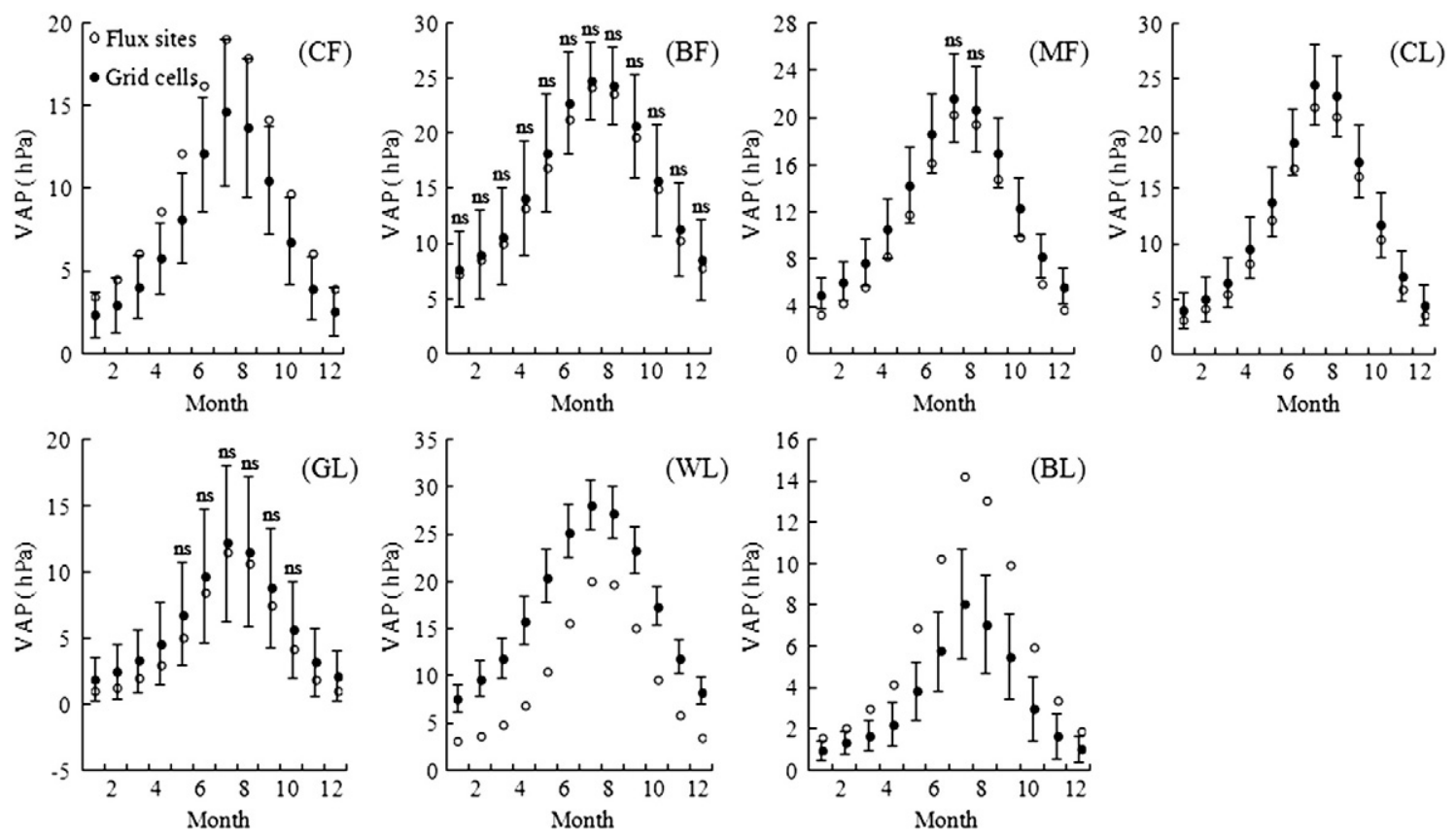

Fig. 4. The vapor pressure (VAP) differences between the flux towers and the grid cells by vegetation type.

flux towers was evidently higher than that of the grid cells for CF and BL. In contrast, the monthly VAP of WL was in the range of 4-10 hPa lower than that of the grid cells. The monthly variations in the EVI indicated that the mean EVI of the BF towers was significantly lower than those of the grid cells (Fig. 5). The EVI distribution of the BL towers was quite different from those of the corresponding grid cells. In terms of the four environmental variables, CL was the most well-represented vegetation type and GL was the second. A significant bias was observed for $\mathrm{WL}$ and $\mathrm{BL}$, and the great uncertainties were observed for the forest data, especially for the BF and CF.

\subsection{Spatial representativeness of the flux network}

Fig. 6a shows the present spatial representativeness of the flux network, which exhibits a wide range of Euclidean distance values, with an average value of $6.46 \pm 3.16$. In this map, the dark-blue to light-blue areas were well represented by the existing set of flux towers and the yellow to red areas were poorly represented. Overall, the lowest distance values were across the northern and eastern parts of China, where the environments were well represented by the existing set of flux towers. The poorest representative area was located at the desert
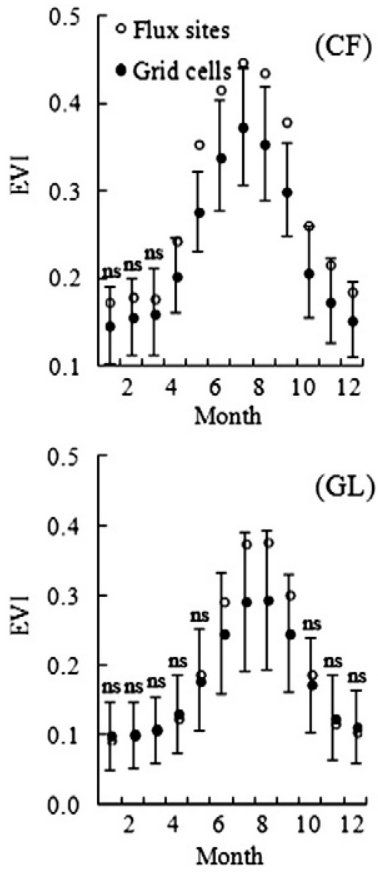
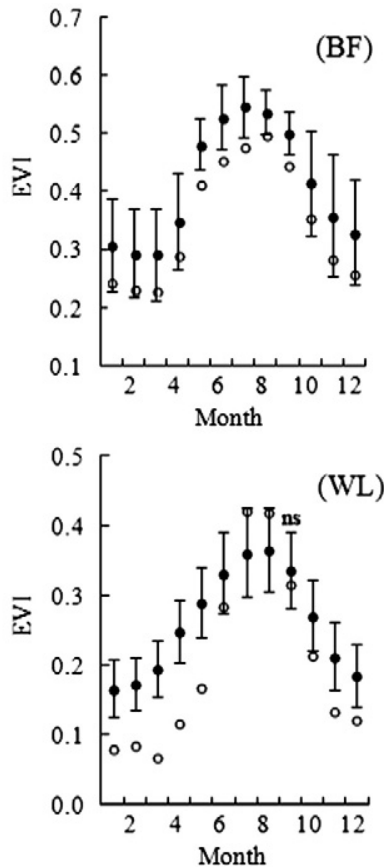
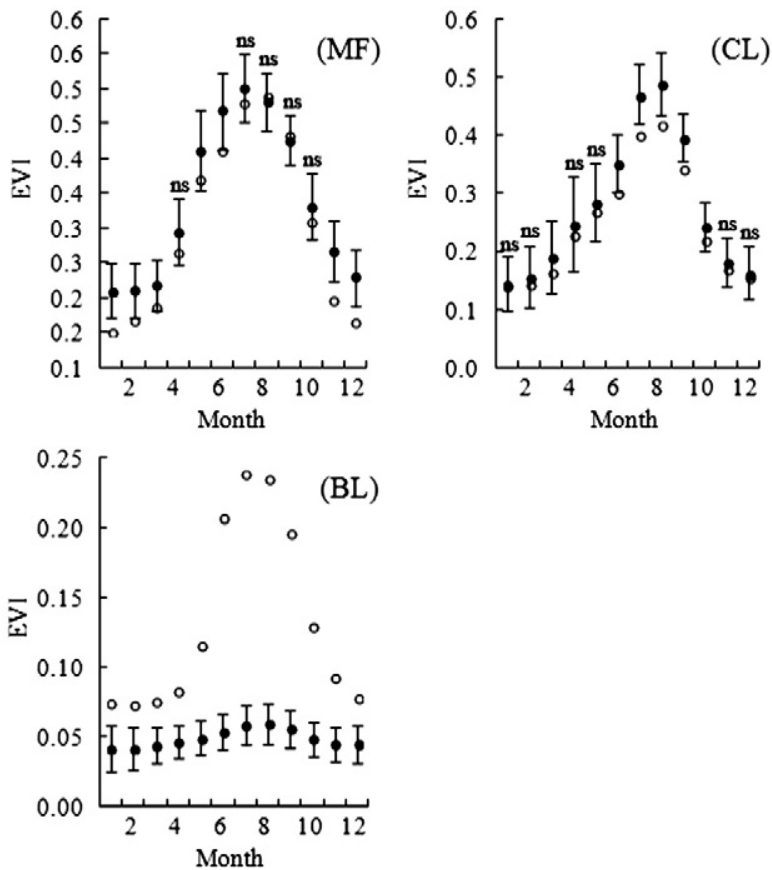

Fig. 5. The vegetation index (EVI) differences between the flux towers and the grid cells by vegetation type. 

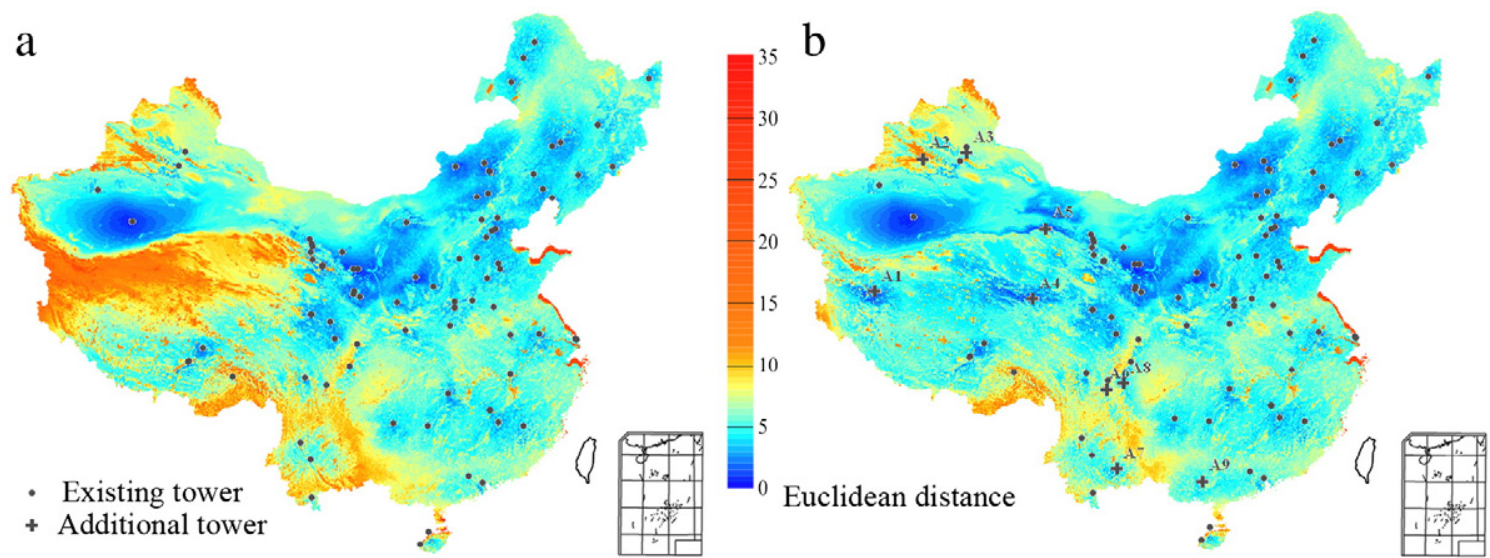

Fig. 6. The spatial representativeness for (a) the present and (b) the optimized network of flux towers in China. Data from Taiwan were not included in this study.

of the northern Tibetan Plateau. In terms of the vegetation type, with the largest number of flux towers, CL and GL had a lower mean Euclidean distance relative to the data of the other vegetation types. The environments of the CL and GL in the central and northeastern portions were especially well-represented by the existing flux towers (Fig. 6a). Meanwhile, the environments of the BL in the northeastern were also represented quite well. In comparison, WL was found to be poorly represented by the existing flux network.

By taking the average of the minimum distances as an indicator, the underrepresented regions could be determined (Fig. 7). A large portion of the northwest and the southeast of the Qinghai-Tibet Plateau were poorly represented. Overall, the well-represented areas, i.e., having a Euclidean distance lower than 6.46 , covered $60.9 \%$ of the total areas (Fig. 7a).

The importance values were calculated for the evaluation of the tower performance in the network. Examination of the importance values of the towers indicated a large variation between the different towers and vegetation types (Table 1). For forests, TSZ (3.6\%), KST (2.82\%), DHF (2.51\%) and DGA (2.12\%) were among the towers with high importance values. For the BL towers, TZZ (8.52\%) and SPTB (2.67\%) had higher importance values. For the towers among the other vegetation types, DXZB (8.20\%), NQZ (8.16\%), DSZ (3.52\%), SNZ (2.04\%), KST (2.82\%), DLAZ (2.50\%) and TYA (2.02\%) had high importance values (Table A.1). Overall, the GL towers had the highest importance values than the other types.

The representativeness of towers exhibited large variation across different vegetation types, ranging from $4.91 \pm 2.02$ to $9.18 \pm 7.03$
(Table 1). However, the average value of $\mathrm{CF}, \mathrm{BF}, \mathrm{GL}$, and WL was higher than the average of the whole flux network (6.46). The variance coefficient of tower representativeness in different vegetation types was decreased from $76.66 \%$ (WL) to $34.05 \%$ (MF). Further, the representativeness of towers varied markedly across different towers in the same vegetation types. For WL, the average value ranged from 4.29 (HBGA) to 24.08 (CMDB), while that of CL varied from $2.76(\mathrm{XLH})$ to 16.32 (SYBZ). In contrast, the average value of BL was less variable, from 3.90 (SPTA) to 6.76 (FKD) (detailed data are listed in Table A.1).

\subsection{Additional tower locations and representativeness improvement}

After analyzing the representativeness of the current flux network, we proposed to improve it by including additional towers that will lead to a better representativeness of the network. The average Euclidean distance of all the grid cells is 6.46; therefore, the pixels with a minimum distance beyond this value were selected for the addition of towers. The additional tower locations to be considered for future construction are presented in Fig. 6b. These towers were distributed at different vegetation types of China, i.e., A1 and A5 were located at BL; A2 and A4 were sited at WL; A3 was located at GL; A6 and A7 were located at $\mathrm{CF}$; and $\mathrm{A} 8$ and $\mathrm{A} 9$ were sited at $\mathrm{BF}$ and $\mathrm{MF}$ (Table 2). Thus, the forests contain $35 \%$ of the additional towers, the croplands contain $26 \%$, the grasslands contain $20 \%$, the wetlands contain $10 \%$ and the barelands contain $9 \%$.

The new representativeness of the flux towers with simultaneous consideration of the 100 towers in total is shown in Fig. $6 \mathrm{~b}$. The mean
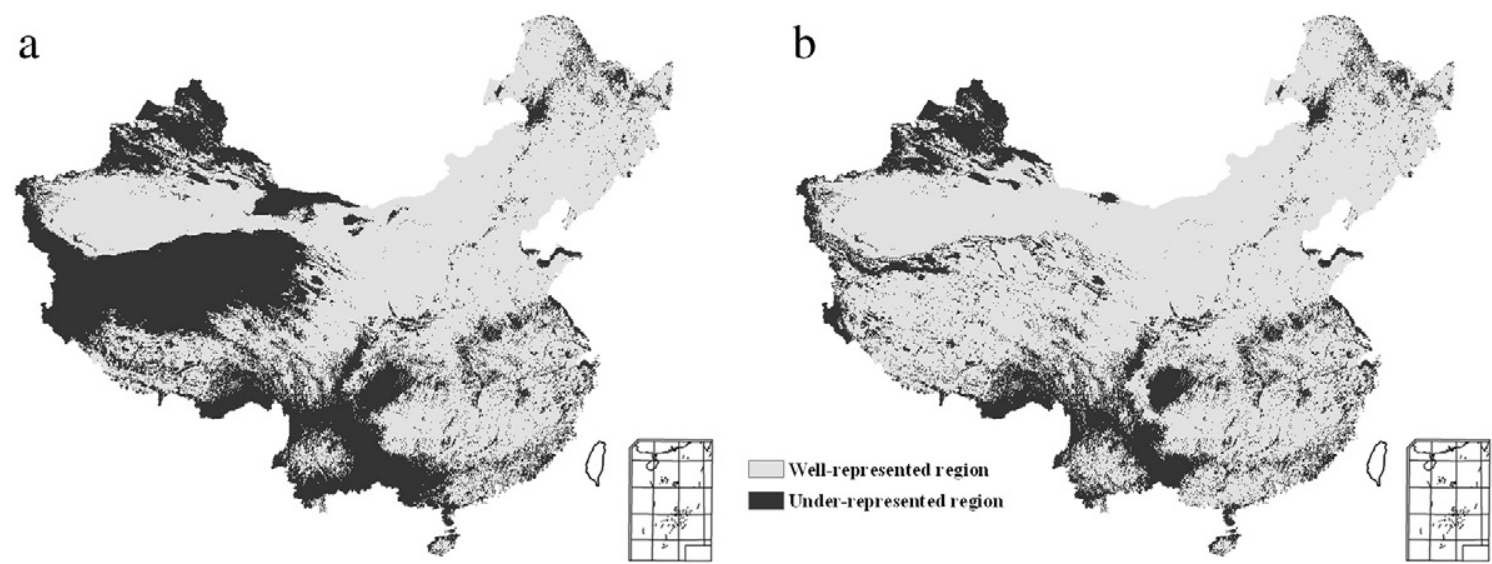

Fig. 7. The comparison of the regional representativeness of (b) the optimized network and (a) the current network. 
Table 1

Importance value in percentage and representativeness of towers for each vegetation type.

\begin{tabular}{lrlll}
\hline $\begin{array}{l}\text { Vegetation } \\
\text { type }\end{array}$ & $\begin{array}{l}\text { Number of flux } \\
\text { towers }\end{array}$ & $\begin{array}{l}\text { Importance } \\
\text { value }(\%)\end{array}$ & $\begin{array}{l}\text { Representativeness of } \\
\text { towers }\end{array}$ \\
\cline { 3 - 5 } & & 13.34 & 6.82 & 2.76 \\
\hline $\mathrm{CF}$ & 9 & 9.15 & 7.63 & 5.30 \\
$\mathrm{BF}$ & 14 & 8.74 & 6.13 & 2.09 \\
$\mathrm{MF}$ & 8 & 17.26 & 6.17 & 3.31 \\
$\mathrm{CL}$ & 19 & 32.11 & 7.42 & 3.73 \\
$\mathrm{GL}$ & 8 & 5.37 & 9.18 & 7.03 \\
$\mathrm{WL}$ & 26 & 14.43 & 4.91 & 2.02 \\
$\mathrm{BL}$ & 7 & & & \\
\hline
\end{tabular}

Euclidean distance of the total region was reduced to 5.46, which is indicated by bluer colors in Fig. 6b compared with Fig. 6a. After including the new towers, the well-represented areas, i.e., those with a Euclidean distance lower than 6.46 , were enlarged by $15.2 \%$ (Fig. $7 \mathrm{~b}$ ) and the coefficient of variation was reduced from $48.9 \%$ to $39.4 \%$.

The improvement of the regional representativeness could be assessed by calculating the reduction of the Euclidean distance of each of the grid cells (Fig. 8). The yellow to red areas were the areas where the representativeness was improved, which occupied $27.5 \%$ of the total areas. Such improvements in the representativeness were especially large in the Tibet Plateau, both in the east central temperate desert and the southwest of the subtropical evergreen broad-leaved forest. The representativeness of the alpine meadow in the Qinghai-Tibet Plateau was improved most significantly.

\section{Discussions}

\subsection{Representativeness of different vegetation types}

An analysis of the monthly variations of the environmental variables revealed that the EVI had the largest variation, which is in accordance with the findings of Yang et al. (2008). The great uncertainties in the EVI measurements indicated the potential of under-representation of the flux towers in terms of the vegetation types. Although nonsignificant differences between the flux towers and the grid cells were found, the great uncertainties in the TEM were also found during the spring and winter of the forest lands. This uncertainty could be related to the large spans of the forests, which are distributed over the cold temperate to temperate zones and the subtropics and tropics areas, thereby resulting in a large difference in temperatures.

In this study, CL was the most well-represented vegetation type, which was followed by GL. The well representativeness of existing flux network for CL was in agreement with the studies of the FLUXNET (Baret et al., 2006). Regarding the GL, the results were confirmed by our tower-based importance analysis, which indicated that the overall importance value of GL towers was evidently higher than those of the other vegetation types. Conversely, with respect to the global distribution, the grassland was found to be underrepresented (Baret et al., 2006), which is inconsistent with our results in China.

Table 2

The locations of the additional flux towers proposed by this study.

\begin{tabular}{llcl}
\hline Code & Latitude $\left({ }^{\circ}\right)$ & Longitude $\left({ }^{\circ}\right)$ & Vegetation type \\
\hline A1 & 33.57 & 82.57 & Bareland \\
A2 & 42.95 & 84.12 & Wetland \\
A3 & 43.90 & 88.00 & Grassland \\
A4 & 34.78 & 95.49 & Wetland \\
A5 & 39.54 & 96.04 & Bareland \\
A6 & 29.01 & 101.95 & Conifer forest \\
A7 & 23.61 & 102.89 & Conifer forest \\
A8 & 29.44 & 103.20 & Broadleaf forest \\
A9 & 22.71 & 109.07 & Mixed forest \\
\hline
\end{tabular}

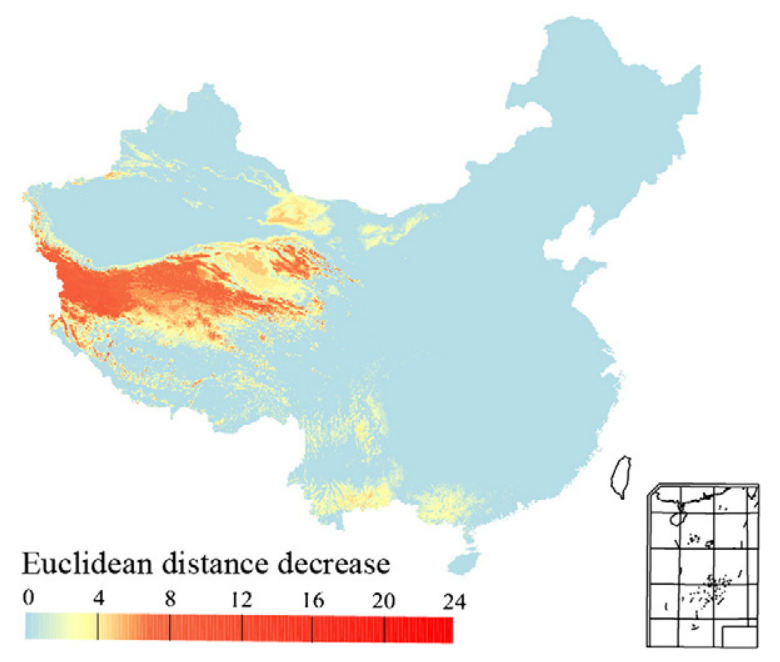

Fig. 8. The improvement in the representativeness by including the additional towers compared to the existing network.

The distinctly high representativeness of the CL and GL in the central of China was largely the result of the large number of flux towers. However, a significant difference in the EVI between the towers of CL and GL and the corresponding pixels during summer was found in this study. Qiu et al. (2013) reported that the MODIS EVI datasets were the least reliable in the summer season during the period of 2001-2011 across China. Regarding the forests, Chen et al. (2012) reported that the flux sites of forests exhibited higher spatial variability than the grassland sites along an east-west continental transect in Canada. The forest towers generally had a good representation of the means of the studied environmental elements in this study. Our results are also supported by the studies of FLUXNET, which had an over representation of the evergreen needleleaf forests and deciduous broadleaf forests (Baret et al., 2006).

A relatively large bias was observed for the BL towers in representing the environmental conditions of the assigned pixels. From a study in the northern China steppes, Price et al. (2003) reported that the desert steppe ecosystem has higher ecological variability than those of the meadow steppe/forest ecosystems. The difference between the pixels and the towers could be caused by the uneven distribution of the existing BL towers, which are located mostly at the ecotone of grassland and desert. Price et al. (2003) indicated greater ecosystem variability in the large areas near the desert steppe ecotone, where a similar variability to those of the desert steppe was exhibited. In this study, only TZZ, which is sited near the center of the Taklimakan Desert, had the greatest importance value, indicating the significant role of the tower in representing the carbon exchange of the regional desert. The EVI for the grid cells in BL was distinctly lower than that of the flux towers. The EVI was primarily controlled by the alpine desert at northwest of the Qinghai-Tibet Plateau, where the EVI was found to be extremely low (Qiu et al., 2013). Li et al. (2013) also reported the decreasing trend of the EVI from the meadow types to the typical steppe types (including improved grassland) and then to the dessert types. In general, the existing flux towers had a good representation of the mean values of the TEM, RAD, VAP and EVI for the different vegetation types, except for WL. This exception is because the wetlands are distributed in a scattered manner across China (Yu et al., 2013), indicating the difficulties associated with the WL studies. Although few towers were found to have great importance values in both WL and BL, these towers are indispensable for capturing or validating the ecosystem behaviors (Yang et al., 2008).

\subsection{Regional representativeness}

The existing flux towers in China were primarily distributed within the $30^{\circ}$ to $50^{\circ}$ latitudes; this distribution is consistent with the results 
obtained by Baret et al. (2006). The representativeness of the network was investigated at $1-\mathrm{km}$ spatial resolution in this study. By taking the regional average as the indicator, the network of flux towers was found to poorly represent the northern Xinjiang as well as the northern and southeastern of Tibetan Plateau. The unique geographical location of the Tibetan Plateau makes the circulation of carbon different from that of the other areas (Yan et al., 2013; Yang et al., 2009). Because of the geographic conditions, the existing tower locations were relatively dispersed and were all in the south and east portions. The southeast of the Tibetan Plateau is known to be an intersection of multiple abiotic gradients, making it difficult to adequately represent all the ecosystem types with the current number of towers. The desert of the northern Tibetan Plateau was especially underrepresented, indicating the current inadequacy of the number of observation towers located in the Tibetan Plateau.

The carbon flux is significantly influenced by the local climatic, geochemical and ecological factors (Potter et al., 2003). Even in the same vegetation types, the differences of representativeness were also significant between flux towers. For example, WL plays a critical role in our ecosystem, the eight towers currently representing $5.37 \%$ areas of mainland China. The representativeness of CMDB was significant higher than the regional value, indicating that more towers in the surrounding area are needed to obtain a better understanding of the local environment. Areas of BL were represented quite well according to the representativeness of towers, and the average of minimum distance of which was distinctly lower than the regional value. However, these towers only represent $14.43 \%$ of areas, which was insufficient comparing with $23.32 \%$ of the land coverage.

The under-represented regions were distributed in a scattered manner in the northeast and southeast. Our observations supported the findings of Hargrove and Hoffman (2004a,b) that it is relatively easy to represent the more average continental interior, but it is much more difficult to achieve adequate representation of unusual regions. The wide variation in the Euclidean distances over China suggested that the findings of the flux towers should be extended to the surrounding regions with caution. The large distances mapped for west and south regions provided a guide to the locations of the additional flux towers that would improve the environmental coverage most significantly.

\subsection{Representativeness improvement}

To improve the regional representativeness, we identified a set of towers complementing the existing flux network. However, the exact number of additional towers required for long-term research is an area of research in itself and depends on the ability of funding agencies to commit to maintaining such long-term sites (Law et al., 2005). In this study, the number of additional towers was set based on an earlier study by Wang et al. (2014), which reported that the total number of flux towers should be in the range between 100 and 150 to cover the major ecosystem types of the country. Unfortunately, it is not possible to establish such a large number of towers because the costs are relatively high (Neyland et al., 2000). Therefore, nine new towers were proposed to maximize the flux network coverage. The distribution of the corresponding towers at different vegetation types appears to be relatively even, except for cropland, which is well represented by the existing network and constitutes the greatest density of towers.

The additional towers performed well in representing the local environmental conditions and compensated for the inadequacy of the existing towers. Hargrove and Hoffman (2003) suggested that the best location for additional flux sites will be in places that are the least well-represented by the network of the existing sites. The Tibetan Plateau region is characterized by very poor vegetation conditions and it exhibits significantly different intra-annual vegetation variability patterns (Qiu et al., 2013). The results showed that substantial gains in representation have been achieved in this region by the addition of new $\mathrm{BL}$ and WL towers (A1, A4 and A5). The region between the Altai
Mountains and the Tianshan Mountains has the longest period of sunshine in the world and enjoys relatively good vegetation conditions (Qiu et al., 2013). The establishment of long-term observation stations (A2 and A3) in this area would play an important role in representing the unique environmental conditions and the pattern of carbon exchanges of the located WL and GL. In contrast, the representativeness of the other regions was improved less distinctly. This lack of improvement is most likely due to the complex topography, highly fragmented ecoregion and distinct vegetation variability during a very short period (Qiu et al., 2013), making them difficult to adequately sample.

When the current network was optimized, the variance of the minimum Euclidian distances was reduced, suggesting a higher capacity of the network to capture the spatial variability. Nonetheless, the variations of the minimum Euclidian distances across the country were quite large, which indicated the shortcomings of these towers in representing the extreme values that determine the spatial variability. By taking the CarboEurope-IP network as an example, Sulkava et al. (2011) reported that the designed networks tend to capture the mean properties of the data space rather than to describe its extremes. Hargrove and Hoffman (2003) added 18 imaginary sites to represent the unusual ecoregions of the United States and suggested that the very different or unusual ecoregions should contain more towers than the average ecoregions.

\section{Conclusions}

We quantified the regional representativeness of the network of eddy flux towers in China by comparing the regional environmental variables with those at the flux towers. We found that the existing network performed well in representing the middle and the northeast regions of China. However, there are large underrepresented regions, especially the northern Tibetan Plateau desert. The towers in croplands and grasslands were well representative for the vegetation types, but the wetlands and barelands were poorly represented by only a few towers. Further, we recommended a means of improving the regional representativeness by adding new towers. These additional tower locations were determined by clustering the underrepresented regions into nine groups. Adding towers in forests, grasslands, wetlands and barelands could increase the representativeness of the existing flux network. In particular, substantial gains in representation would be achieved by adding new towers on the Tibetan Plateau. Influenced by the complex environments, the representativeness of the northwest and southwest was improved less significantly by the addition of towers, suggesting more towers are required to capture certain ecosystem behaviors.

\section{Conflict of interest}

We declare that we have no financial and personal relationships with other people or organizations that can inappropriately influence our work, there is no professional or other personal interest of any nature or kind in any product, service and/or company that could be construed as influencing the position presented in, or the review of, the manuscript entitled "Regional representativeness assessment and improvement of eddy flux observations in China".

\section{Acknowledgments}

We gratefully acknowledge the financial support received for this work from the "Strategic Priority Research Program - Climate Change: Carbon Budget and Relevant Issues" of the Chinese Academy of Sciences (Grant No. XDA05050600) and the National Key Research and Development Program (Grant No. 2010CB833500). 
Appendix A

Table A.1

The locations, importance value and representativeness of the flux towers used in this study.

\begin{tabular}{|c|c|c|c|c|c|c|}
\hline \multirow[t]{2}{*}{ Code } & \multirow[t]{2}{*}{ Latitude $\left({ }^{\circ}\right)$} & \multirow[t]{2}{*}{ Longitude $\left({ }^{\circ}\right)$} & \multirow[t]{2}{*}{ Vegetation type } & \multirow[t]{2}{*}{ Importance value (\%) } & \multicolumn{2}{|c|}{ Representativeness of towers } \\
\hline & & & & & Mean & Standard deviation \\
\hline JFL & 18.67 & 108.82 & Broadleaf forest & 0.04 & 15.53 & 10.81 \\
\hline DZAZ & 19.53 & 109.47 & Broadleaf forest & 0.37 & 8.14 & 4.04 \\
\hline BNF & 21.95 & 101.20 & Broadleaf forest & 0.63 & 8.88 & 2.89 \\
\hline ZJS & 22.70 & 113.50 & Broadleaf forest & 0.85 & 17.58 & 9.77 \\
\hline $\mathrm{DHF}$ & 23.17 & 112.53 & Broadleaf forest & 2.51 & 7.58 & 3.16 \\
\hline ALF & 24.54 & 101.02 & Broadleaf forest & 0.78 & 8.66 & 3.68 \\
\hline DLAZ & 25.69 & 100.19 & Cropland & 2.50 & 8.41 & 2.14 \\
\hline QYZA & 26.25 & 116.92 & Cropland & 1.86 & 6.61 & 2.59 \\
\hline QYZB & 26.73 & 115.07 & Conifer forest & 1.74 & 5.42 & 1.58 \\
\hline HTF & 26.83 & 109.75 & Conifer forest & 0.63 & 6.06 & 1.70 \\
\hline KST & 27.05 & 107.12 & Mixed forest & 2.82 & 6.15 & 1.37 \\
\hline DGA & 27.58 & 114.57 & Conifer forest & 2.12 & 7.00 & 3.47 \\
\hline DGB & 27.59 & 114.57 & Broadleaf forest & 0.00 & 0.00 & 0.00 \\
\hline DGC & 27.59 & 114.57 & Broadleaf forest & 0.00 & 0.00 & 0.00 \\
\hline TYA & 28.92 & 111.45 & Cropland & 2.02 & 5.35 & 1.26 \\
\hline GGF & 29.58 & 102.00 & Mixed forest & 0.20 & 9.56 & 1.44 \\
\hline LZF & 29.77 & 94.58 & Mixed forest & 1.12 & 9.18 & 2.71 \\
\hline $\mathrm{BPZ}$ & 29.83 & 116.43 & Mixed forest & 0.80 & 5.71 & 1.05 \\
\hline LTZ & 30.03 & 100.28 & Grassland & 1.04 & 5.98 & 1.48 \\
\hline DXZA & 30.41 & 91.01 & Wetland & 0.30 & 5.75 & 2.16 \\
\hline DXZB & 30.50 & 91.07 & Grassland & 8.20 & 9.01 & 3.61 \\
\hline WJZ & 30.97 & 103.81 & Cropland & 0.41 & 6.30 & 1.14 \\
\hline NQZ & 31.50 & 92.01 & Grassland & 8.16 & 10.07 & 3.52 \\
\hline CMDA & 31.52 & 121.96 & Wetland & 0.16 & 6.36 & 2.65 \\
\hline CMDB & 31.52 & 121.97 & Wetland & 0.91 & 24.08 & 1.60 \\
\hline CMDC & 31.58 & 121.90 & Wetland & 0.40 & 7.75 & 2.62 \\
\hline XSC & 32.30 & 119.13 & Mixed forest & 1.96 & 5.26 & 1.07 \\
\hline WLZ & 32.42 & 104.33 & Conifer forest & 1.03 & 7.72 & 1.86 \\
\hline SXZ & 32.50 & 116.77 & Cropland & 0.87 & 6.36 & 1.04 \\
\hline HYZ & 32.78 & 102.53 & Wetland & 1.49 & 6.99 & 2.42 \\
\hline QLF & 33.30 & 108.33 & Conifer forest & 1.48 & 5.55 & 1.35 \\
\hline BTM & 33.47 & 111.98 & Mixed forest & 0.37 & 6.58 & 1.77 \\
\hline MQZ & 33.89 & 102.14 & Grassland & 0.24 & 7.58 & 8.63 \\
\hline SJY & 34.35 & 100.48 & Grassland & 1.81 & 4.94 & 1.34 \\
\hline GLZ & 34.35 & 100.56 & Grassland & 0.23 & 7.65 & 8.21 \\
\hline SQA & 34.44 & 115.65 & Cropland & 0.30 & 9.83 & 3.15 \\
\hline LYA & 34.63 & 112.46 & Cropland & 0.32 & 5.45 & 1.06 \\
\hline LYAZ & 34.70 & 112.44 & Cropland & 0.15 & 5.17 & 1.68 \\
\hline FQA & 35.00 & 114.00 & Cropland & 0.74 & 6.33 & 1.19 \\
\hline HHX & 35.02 & 112.47 & Broadleaf forest & 0.46 & 4.44 & 1.21 \\
\hline CWA & 35.20 & 107.67 & Cropland & 0.66 & 6.35 & 2.96 \\
\hline DXAZ & 35.55 & 104.58 & Cropland & 0.41 & 4.87 & 2.64 \\
\hline XLS & 35.77 & 104.05 & Cropland & 0.35 & 5.33 & 1.44 \\
\hline YZZ & 35.95 & 104.13 & Grassland & 0.47 & 3.57 & 1.63 \\
\hline JXF & 36.12 & 110.81 & Broadleaf forest & 1.27 & 5.19 & 1.76 \\
\hline GGZ & 36.47 & 115.40 & Cropland & 0.47 & 4.87 & 0.99 \\
\hline ASA & 36.85 & 109.32 & Cropland & 1.04 & 3.62 & 1.28 \\
\hline YCA & 36.95 & 116.63 & Cropland & 0.43 & 4.48 & 1.05 \\
\hline DZBZ & 37.33 & 116.48 & Cropland & 0.74 & 4.42 & 0.90 \\
\hline SPTA & 37.46 & 104.01 & Bareland & 0.79 & 3.90 & 1.98 \\
\hline SPTB & 37.50 & 104.43 & Bareland & 2.67 & 5.62 & 2.46 \\
\hline HBGA & 37.60 & 101.32 & Wetland & 0.30 & 4.59 & 1.92 \\
\hline HBGB & 37.62 & 101.30 & Grassland & 0.05 & 3.53 & 0.95 \\
\hline HBGC & 37.67 & 101.33 & Grassland & 0.25 & 5.33 & 2.49 \\
\hline SYBZ & 37.88 & 113.17 & Cropland & 0.87 & 16.32 & 9.31 \\
\hline LCA & 37.88 & 114.68 & Cropland & 0.16 & 4.86 & 1.25 \\
\hline ARD & 38.04 & 100.46 & Grassland & 0.04 & 9.57 & 3.04 \\
\hline DYK & 38.53 & 100.25 & Conifer forest & 0.43 & 6.29 & 1.87 \\
\hline MQD & 38.57 & 102.98 & Bareland & 0.13 & 4.40 & 1.62 \\
\hline YKZ & 38.86 & 100.41 & Cropland & 0.17 & 5.86 & 2.46 \\
\hline $\mathrm{TZZ}$ & 39.00 & 84.40 & Bareland & 8.52 & 4.53 & 1.74 \\
\hline $\mathrm{ZYZ}$ & 39.08 & 100.27 & Bareland & 1.00 & 6.55 & 1.40 \\
\hline GCZ & 39.13 & 115.67 & Cropland & 0.07 & 3.64 & 0.73 \\
\hline LZD & 39.33 & 100.12 & Cropland & 0.18 & 4.99 & 1.91 \\
\hline DXBZ & 39.52 & 116.25 & Broadleaf forest & 0.39 & 3.94 & 1.01 \\
\hline LFZ & 39.60 & 116.58 & Cropland & 0.30 & 3.96 & 1.26 \\
\hline SDQ & 40.33 & 115.42 & Broadleaf forest & 0.27 & 4.45 & 0.78 \\
\hline MYZ & 40.37 & 116.85 & Cropland & 0.27 & 6.13 & 2.65 \\
\hline KBQ & 40.53 & 108.68 & Grassland & 1.78 & 4.60 & 1.34 \\
\hline AKA & 40.62 & 80.75 & Cropland & 0.42 & 5.52 & 1.58 \\
\hline
\end{tabular}


Table A.1 (continued)

\begin{tabular}{|c|c|c|c|c|c|c|}
\hline \multirow[t]{2}{*}{ Code } & \multirow[t]{2}{*}{ Latitude $\left({ }^{\circ}\right)$} & \multirow[t]{2}{*}{ Longitude $\left({ }^{\circ}\right)$} & \multirow[t]{2}{*}{ Vegetation type } & \multirow[t]{2}{*}{ Importance value (\%) } & \multicolumn{2}{|c|}{ Representativeness of towers } \\
\hline & & & & & Mean & Standard deviation \\
\hline PJZ & 41.13 & 121.90 & Wetland & 0.51 & 4.29 & 0.83 \\
\hline $\mathrm{JZZ}$ & 41.82 & 121.20 & Cropland & 0.70 & 4.19 & 1.01 \\
\hline DSS & 41.90 & 115.30 & Grassland & 1.13 & 3.83 & 0.90 \\
\hline DLBZ & 42.05 & 116.27 & Grassland & 0.82 & 5.34 & 1.52 \\
\hline BLS & 42.33 & 124.75 & Mixed forest & 0.73 & 4.61 & 1.02 \\
\hline CBF & 42.40 & 128.01 & Mixed forest & 0.74 & 4.56 & 1.25 \\
\hline NMD & 42.92 & 120.70 & Bareland & 0.77 & 4.22 & 0.85 \\
\hline TSZ & 43.32 & 87.52 & Conifer forest & 3.60 & 8.76 & 3.00 \\
\hline XLH & 43.55 & 116.67 & Grassland & 0.02 & 2.76 & 1.26 \\
\hline NMG & 43.55 & 116.68 & Grassland & 0.19 & 5.45 & 3.06 \\
\hline DSZ & 44.08 & 113.57 & Grassland & 3.52 & 6.26 & 2.00 \\
\hline ZLG & 44.13 & 116.32 & Grassland & 1.32 & 4.34 & 1.69 \\
\hline FKD & 44.28 & 87.92 & Bareland & 0.55 & 6.76 & 2.11 \\
\hline TYZ & 44.57 & 122.88 & Cropland & 0.85 & 4.08 & 1.14 \\
\hline SNZ & 44.70 & 123.75 & Grassland & 2.04 & 5.01 & 1.07 \\
\hline LSZ & 45.33 & 127.57 & Broadleaf forest & 0.11 & 4.54 & 1.50 \\
\hline MEF & 45.38 & 127.53 & Broadleaf forest & 1.47 & 5.50 & 1.35 \\
\hline SJM & 47.58 & 133.52 & Wetland & 1.30 & 5.88 & 0.95 \\
\hline HLG & 49.33 & 119.94 & Grassland & 0.80 & 5.20 & 1.65 \\
\hline DXF & 50.83 & 121.56 & Conifer forest & 1.63 & 5.45 & 1.27 \\
\hline $\mathrm{HZZ}$ & 51.78 & 123.01 & Conifer forest & 0.68 & 5.35 & 1.76 \\
\hline
\end{tabular}

\section{References}

Amthor JS. Plant respiratory responses to elevated $\mathrm{CO}_{2}$ partial pressure. In: Allen $\mathrm{LH}$, Kirkham MB, Olszyk DM, Whitman CE, editors. Advances in carbon dioxide effects research. American Society of Agronomy Special Publication (Proceedings of 1993 ASA Symposium, Cincinnati, OH)Madison, WI: ASA, CSSA and SSSA; 1997. p. 35-77.

Baldocchi D. Breathing of the terrestrial biosphere: lessons learned from a global network of carbon dioxide flux measurement systems. Aust J Bot 2008;56:1-26.

Baldocchi D, Falge E, Gu L, Olson R, Hollinger D, Running S, et al. FLUXNET: a new tool to study the temporal and spatial variability of ecosystem-scale carbon dioxide, water vapor and energy flux densities. Bull Am Meteorol Soc 2001;82:2415-34.

Baret F, Morisette J, Fernandes R, Champeaux J-L, Myneni RB, Chen J, et al. Evaluation of the representativeness of networks of sites for the global validation and intercomparison of land biophysical products. Proposition of the CEOS-BELMANIP. IEEE Trans Geosci Remote Sens 2006;44(7):1794-803.

Canadell JG, Ciais P, Cox P, Heimann M. Quantifying, understanding and managing the carbon cycle in the next decades. Clim Chang 2004;67:147-60.

Carvalhais N, Reichstein M, Collatz GJ, Mahecha MD, Migliavacca M, Neigh CSR, et al. Deciphering the components of regional net ecosystem fluxes following a bottomup approach for the Iberian Peninsula. Biogeosciences 2010;7(11):3707-29.

Chapin III FS, Matson PA, Mooney H. Principles of terrestrial ecosystem ecology. New York, New York, USA: Springer-Verlag; 2002.

Chen B, Coops NC, Fu D, Margolis HA, Amiro BD, Black TA, et al. Characterizing spatial representativeness of flux tower eddy covariance measurements across the Canadian Carbon Program Network using remote sensing and footprint analysis. Remote Sens Environ 2012;124:742-55.

Chen Z, Yu G, Ge J, Sun X, Hirano T, Saigusa N, et al. Temperature and precipitation control of the spatial variation of terrestrial ecosystem carbon exchange in the Asian region. Agric For Meteorol 2013;182-183:266-76.

Dan L, Ji JJ, Li YP. Climatic and biological simulations in a two-way coupled atmospherebiosphere model (CABM). Global Planet Chang 2005;47:153-69.

Editorial Board of Vegetation Map of China. Chinese Academy of Sciences, 1:1000000 Vegetation Atlas of China. Beijing: Geological Publishing House. 2007.

Feng S, Hu Q, Qian W. Quality control of daily meteorological data in China, 1951-2000: a new dataset. Int J Climatol 2004;24:853-70.

Fu BJ, Li SG, Yu XB, Yang P, Yu GR, Feng RG, et al. Chinese ecosystem research network: progress and perspectives. Ecol Complex 2010;7:225-33.

Gao YH, Zhou X, Wang Q, Wang CZ, Zhan ZM, Chen LF, et al. Vegetation net primary productivity and its response to climate change during 2001-2008 in the Tibetan Plateau. Sci Total Environ 2013;444:356-62.

Gong LJ, Liu SM, Shuang X, Cai XH, Xu ZW. Investigation of spatial representativeness for surface flux measurements with eddy covariance system and large aperture scintillometer. Plateau Meteorol 2009;28(2):246-57.

Gonzalez-Meler MA, Taneva L, Trueman RJ. Plant respiration and elevated atmospheric $\mathrm{CO}_{2}$ concentration: cellular responses and global significance. Ann Bot Lond 2004; 94(5):647-56.

Granier A, Reichstein M, Bréda N, Janssens IA, Falge E, Ciais P, et al. Evidence for soil water control on carbon and water dynamics in European forests during the extremely dry year: 2003. Agric For Meteorol 2007;143(1-2):123-45.

Gurung RB, Breidt FJ, Dutin A, Ogle SM. Predicting enhanced vegetation index (EVI) curves for ecosystem modeling applications. Remote Sens Environ 2009;113(10):2186-93.

Hargrove WW, Hoffman FM. Representativeness and network site analysis based on quantitative ecoregions. Web page at http://research.esd.ornl.gov/ hnw/networks/, 2003.
Hargrove WW, Hoffman FM. Potential of multivariate quantitative methods for delineation and visualisation of ecoregions. Environ Manag 2004a;34:S39-60.

Hargrove WW, Hoffman FM. A flux atlas for representativeness and statistical extrapolation of the AmeriFlux network. ORNL Technical Memorandum ORNL/TM-2004/112. Available at http://geobabble.ornl.gov/flux-ecoregions/, 2004.

Hartigan JA. Clustering algorithms. New York: Wiley; 1975

He HL, Liu M, Sun XM, Zhang L, Luo YQ, Wang HM, et al. Uncertainty analysis of eddy flux measurements in typical ecosystems of ChinaFLUX. Ecol Inf 2010;5:492-502.

Hoffman FM, Hargrove WW, Mills RT, Mahajan S, Erickson DJ, Oglesby RJ. Multivariate Spatio-Temporal Clustering (MSTC) as a data mining tool for environmental applications. In: Sàànchez-Marrè M, Béjar J, Comas J, Rizzoli AE, Guariso G, editors. Proceedings of the iEMSs fourth biennial meeting: international congress on environmental modelling and software society (iEMSs 2008); 2008. p. 1774-81.

Hoffman FM, Kumar J, Mills RT, Hargrove WW. Representativeness-based sampling network design for the State of Alaska. Landsc Ecol 2013;28:1567-86.

Huete A, Didan K, Miura T, Rodriguez E. Overview of the radiometric and biophysical performance of the MODIS vegetation indices. Remote Sens Environ 2002;83(1-2): 195-213.

Hutchinson MF. The application of thin-plate smoothing splines to continent-wide data assimilation. In: Jasper JD, editor. Data assimilation systems. BMRC Res. Report No. 27. Molbourne: Bureau of Meteorology; 1991. p. 104-13.

Hutchinson MF. Interpolating mean rainfall using thin plate smoothing splines. Int J Geogr Inf Syst 1995;9:305-403.

Hutchinson MF. Interpolation of rainfall data with thin plate smoothing splines-I: two dimensional smoothing of data with short range correlation. J Geogr Inf Decis Anal 1998;2:152-67.

Hutchinson MF. ANUSPLIN version 4.2 user guide; 2002.

Law BE, Loescher HW, Boden TA, Hargrove WW, Hoffman FM. Ameriflux site evaluation and recommendations for network enhancement. Oak Ridge: Oak Ridge National Laboratory; 2005.

Li S, Xie Y, Brown DG, Bai Y, Hua J, Judd K. Spatial variability of the adaptation of grassland vegetation to climatic change in Inner Mongolia of China. Appl Geogr 2013;43:1-12.

Mi N, Yu GR, Wang PX, Wen XF, Sun XM. A preliminary study for spatial representativeness of flux observation at ChinaFLUX sites. Sci China Ser D 2006;49(Suppl. 2):24-35.

Nappo CJ, Caneill JY, Furman RW, Gifford FA, Kaimal JC, Kramer ML, et al. The workshop on the representativeness of meteorological observations. June 1981, Boulder, Colo. Bull Am Meteorol Soc 1982;63:761-4.

Neyland MG, Brown MJ, Su W. Assessing the representativeness of longterm ecological research sites: a case study at Warra in Tasmania. Aust For 2000;63:194-8.

Potter C, Klooster S, Steinbach M, Tan P, Kumar V, Shekhar S, et al. Global teleconnections of climate to terrestrial carbon flux. J Geophys Res 2003;108(D17):4556.

Price K, Yu F, Lee R, Ellis J. Characterizing ecosystem variability of northern China steppes using onset of green-up derived from time-series AVHRR NDVI data. Proc. SPIE 4890, ecosystems dynamics, ecosystem-society interactions, and remote sensing applications for semi-arid and arid land 880; 2003.

Qin Z, Ouyang Y, Su G, Yu Q Li J, Zhang J, et al. Characterization of $\mathrm{CO}_{2}$ and water vapor fluxes in a summer maize field with wavelet analysis. Ecol Inf 2008;3:397-409.

Qiu BW, Zeng CY, Tang ZH, Chen CC. Characterizing spatiotemporal non-stationarity in vegetation dynamics in China using MODIS EVI dataset. Environ Monit Assess 2013;185(11):9019-35.

Schlesinger WH. Biogeochemistry: an analysis of global change. 2nd ed. San Diego, CA: Academic Press; 1997.

Shuang X, Liu CM, Xu ZW, Wang WZ. Investigation of spatial representativeness for surface flux measurements in the Heihe river basin. Adv Earth Sci 2009;24(7):724-33. 
Sulkava M, Luyssaert S, Zaehle S, Papale D. Assessing and improving the representativeness of monitoring networks: the European flux tower network example. J Geophys Res 2011;116:G00j04.

Thomas MV, Malhi Y, Fenn KM, Fisher JB, Morecroft MD, Lloyd CR, et al. Carbon dioxide fluxes over an ancient broadleaved deciduous woodland in southern England. Biogeosciences 2011;8:1595-613.

Thornton PE, Law BE, Ghol HL, Clark KL, Falge E, Ellsworth DS, et al. Modeling and measuring the effects of disturbance history and climate on carbon and water budgets in evergreen needle leaf forests. Agric For Meteorol 2002;113(1):185-222.

Valentini R, editor. Fluxes of carbon, water and energy of European forests. Ecological studies. Berlin: Springer 3-540-43791-6; 2003.

Wang HM, Saigusa N, Zu YG, Wang WJ, Yamamoto S, Kondo H. Carbon fluxes and their response to environmental variables in a Dahurian larch forest ecosystem in northeast China. J For Res Jpn 2008;19(1):1-10.

Wang W, Liao YC, Wen XX, Guo Q. Dynamics of $\mathrm{CO}_{2}$ fluxes and environmental responses in the rain-fed winter wheat ecosystem of the Loess Plateau, China. Sci Total Environ 2013;461-462:10-8.

Wang SQ Chen DC, Zhou L, He HL, Shi P, Yan HM, et al. Assessing the spatial representativeness of eddy covariance flux observation stations of terrestrial ecosystems in China. Acta Ecol Sin 2014;33:7715-28.

Wofsy SC, Goulden ML, Munger JW, Fan SM, Bakwin PS, Daube BC, et al. Net exchange of $\mathrm{CO}_{2}$ in a mid-latitude forest. Science 1993;260:1314-7.
Xiao X, Zhang Q, Braswell B, Urbanski S, Boles S, Wofsy SC, et al. Modeling gross primary production of a deciduous broadleaf forest using satellite images and climate data. Remote Sens Environ 2004;91:256-70.

Xiao JF, Zhuang QL, Law BE, Baldocchi DD, Chen JQ, Richardson AD, et al. Assessing ne ecosystem carbon exchange of U.S. terrestrial ecosystems by integrating eddy covariance flux measurements and satellite observations. Agric For Meteorol 2011; 151:60-9.

Xiao J, Chen J, Davis KJ, Reichstein M. Advances in upscaling of eddy covariance measurements of carbon and water fluxes. J Geophys Res 2012;117:G00J01.

Yan J, Zhang JH, Xu XD, Dong ZX. A GPP assimilation model for the southeastern Tibetan Plateau based on $\mathrm{CO}_{2}$ eddy covariance flux tower and remote sensing data. Int J Appl Earth Obs 2013;23:213-25.

Yang F, Zhu A-X, Ichii K, White MA, Hashimoto H, Nemani RR. Assessing the representativeness of the AmeriFlux network using MODIS and GOES data. J Geophys Res 2008; 113:G04036.

Yang K, Chen YY, Qin J. Some practical notes on the land surface modeling in the Tibetan Plateau. Hydrol Earth Syst Sci 2009;13(5):687-701.

Yu GR, Wen XF, Sun XM, Tanner BD, Lee XH, Chen JY. Overview of ChinaFLUX and evaluation of its eddy covariance measurement. Agric For Meteorol 2006;137:125-37.

Yu GR, Zhu XJ, Fu YL, He HL, Wang QF, Wen XF, et al. Spatial pattern and climate drivers of carbon fluxes in terrestrial ecosystems of China. Glob Chang Biol 2013;19(3): 798-810. 